\title{
PELATIHAN MANAJEMEN REFERENSI: STRATEGI MENGHINDARI AKSI PLAGIARISME DI KALANGAN MAHASISWA MENGGUNAKAN ZOTERO
}

\author{
Atiqa Nur Latifa Hanum, Sahidi, Sisilya Saman Madeten dan Amriani Amir \\ Program Studi D3 Perpustakaan, Fakultas Keguruan dan Ilmu Pendidikan, Universitas Tanjungpura \\ E-mail: atiqa.nur@fkip.untan@ac.id
}

\begin{abstract}
ABSTRAK. Tingginya aksi plagiarisme di kalangan akademisi terutama mahasiswa masih marak dilakukan. Celah dan peluang untuk melakukan kecurangan guna menghasilkan sebuah karya ilmiah terus dilakukan dengan berbagai alasan yang mendesak. Upaya yang dapat dilakukan salah satunya memberikan edukasi kepada para mahasiswa melalui pelatihan manajemen referensi menggunakan aplikasi zotero. Tujuannya untuk menganalisis kecenderungan tindakan plagiarisme yang menyebabkan mereka mengabaikan kaidah dan etika serta melatih mereka untuk tertib saat melakukan penulisan sebuah karya ilmiah. Metode yang digunakan berupa sosialisasi dan pelatihan oleh tim pelaksana pengabdian sesuai dengan keahlian bidangnya. Kegiatan dilakukan secara daring selama 3 hari berturut-turut. Hasilnya menunjukkan bahwa semua peserta pelatihan mengetahui adanya aplikasi manajemen referensi seperti zotero untuk mempermudah penulisan karya ilmiah namun mengabaikannya karena ketidakpahaman dalam penggunaan, informasi yang diperoleh berasal dari sumber bebas, kurangnya keterampilan literasi informasi, serta keterbatasan waktu untuk menyelesaikan menjadi permasalahan utama tindakan plagiarisme dilakukan di kalangan mahasiswa. Setelah mengikuti pelatihan, sebanyak $63,3 \%$ peserta merasa kemampuan kognitif dan afektifnya bertambah.
\end{abstract}

Kata kunci: manajemen referensi, plagiarisme, zotero

ABSTRACT. The plagiarism among scholars, especially students, is in the high level. The opportunities for cheating in writing scientific paper is still continuing for the various urgent reasons. One of the preventive efforts was training reference management using the zotero application for the students. The purposes were to analyze the tendency of plagiarism and the reason of ignoring rules and ethics in scientific writing, and to train them writing a scientific paper properly. The method used is educating and training by the community service implemented by the skilled trainer. The program was conducted via online in 3 days. The results showed that all participants were aware of reference management applications such as zotero to facilitate writing scientific papers but they ignored them due to incomprehension in use, information obtained from free sources, lack of information literacy skills, and limited time to finish the papers being the main problem of plagiarism. After attending the training, there were $63.3 \%$ of participants agreed their cognitive and affective abilities had increased.

Keywords: reference management, plagiarism, zotero

\section{PENDAHULUAN}

Dunia akademik tidak terlepas dari kegiatan tri dharma perguruan tinggi. Tingginya produktivitas karyailmiahyang dihasilkan oleh para akademisihasil kegiatan dari tri dharma perguruan tinggi menuntut para penulis untuk lebih cermat dan bijaksana dalam menggunakan referensi untuk penulisan karya ilmiah mereka. Hal tersebut dikarenakan banyak diantara para penulis yang tidak memahami cara pengutipan maupun mensitasi karya cipta penulis lain. Oleh sebab itu, para penulis rawan terhadap pelanggaran hak cipta karya penulis lain atau biasa disebut dengan tindakan plagiarisme.

Banyak faktor yang menyebabkan para penulis sampai melakukan pelanggaran tersebut, diantaranya karena minimnya pengetahuan tentang etika pengutipan, cara mensitasi, kelalaian mencantumkan sumber yang telah digunakan sebagai referensi penulisan karya ilmiah, dan lain sebagainya. Jika sudah demikian para penulis harus berlapang dada menerima konsekuensinya, mulai dari pencabutan gelar berdasarkan UU No.20 Tahun 2003 tentang Sistem Pendidikan Nasional pasal 25 ayat 2, pembatalan ijazah berdasarkan Peraturan Menteri
Pendidikan dan Kebudayaan No.17 Tahun 2010 tentang Pencegahan dan Penanggulangan Plagiat di Perguruan Tinggi pasal 12 ayat 1 huruf g, hingga ancaman pidana penjara paling lama dua tahun dan/ atau pidana denda paling banyak Rp 200,000,000,(dua ratus juta) berdasarkan UU No.20 Tahun 2003 tentang Sistem Pendidikan Nasional pasal 70. Beberapa data kasus pelanggaran plagiarisme dalam dunia akademik terekam seperti pengunduran diri guru besar di salah satu kampus negeri ternama di Yogyakarta(Merdeka, 17/02/2014), pencopotan gelar profesor salah satu pengajar dan ia juga diberhentikan secara tidak hormat oleh kampus swasta ternama di Bandung (Detiknews, 09/02/2010), serta rektor kampus negeri ternama di Jakarta dicopot sementara (BBC, 28/09/2017).

Kasus pelanggaran tersebut dapat diminimalisir dengan diberikannya edukasi melalui sosialisasi dan pelatihan bagi para calon penulis maupun para penulis aktif yang akan menghasilkan karya tulis. Fenomena di dunia akademik, baru-baru ini berdasarkan data kajian yang dilakukan oleh Charismiadji, tindakan plagiarisme sudah dimulai dari pada jenjang sekolah dasar hingga menengah 
bahkan angkanya mencapai 94\% (Jawapos, 27/04/2021). Pada tingkat perguruan tinggi, tindakan plagiarisme dilakukan baik oleh mahasiswa, dosen, bahkan rektor. Sama halnya dengan siswa, mahasiswa mulai dari semester pertama hingga akhir selalu dituntut untuk menyelesaikan tugas dari dosen dengan mencantumkan referensi bacaan yang digunakan untuk menyelesaikan tugas invidu maupun kelompok. Akan tetapi, para dosen sering menemukan kesalahan-kesalahan yang dilakukan oleh mahasiswa terkait sitasi maupun penulisan daftar bibliografi. Termasuk juga menggunakan sumber referensi yang tidak kredibel (terpercaya).

Berdasarkan kajian yang dilakukan oleh tim pelaksana pengabdian terhadap tugas akhir mahasiswa dalam tiga tahun terakhir (tahun 2017 -2019), diperoleh sebanyak $87 \%$ mahasiswa tingkat akhir program studi perpustakaan FKIP Universitas Tanjungpura melakukan tindakan plagiarisme parsial dan antarbahasa, khususnya pada bab 2 (kajian teori). Para mahasiswa tingkat akhir sangat perlu memahami dengan baik manajemen referensi karya ilmiah. Sebagian besar mahasiswa tingkat akhir memiliki permasalahan pada cara pengutipan maupun pencantuman sumber kutipan serta penyusunan daftar bibliografi. Oleh karena itu, perlu dilakukannya edukasi agar memudahkan mereka menyelesaikan penulisan tugas akhir sebagai syarat kelulusan tanpa perlu melakukan tindakan plagiarisme yang disengaja maupun yang tidak disengaja.

Salah satu solusi untuk mengatasi permasalahan tersebut yakni dengan menguasai manajemen referensi karya ilmiah. Beberapa keuntungan yang akan diperoleh seperti memudahkan melakukan sitiran terhadap sumber referensi yang digunakaan saat menulis tugas akhir (skripsi/tesis/disertasi), sumber elektronik yang digunakan bisa tersimpan dengan rapi pada database aplikasi, sumber tersebut mudah untuk ditemukan kembali jika sewaktu-waktu diperlukan, serta memudahkan dan menghemat waktu pembuatan bibliografi.

Pengetahuan yang diperoleh melalui edukasi manajemen referensi karya ilmiah akan sangat bermanfaat bagi mahasiswa tingkat akhir. Selain memudahkan mereka menyelesaikan tugas akhir, pengetahuan tersebut berguna bagi mereka saat menjadi pustakawan nantinya terutama saat menjalankan perannya sebagai edukator. Mereka dapat membimbing pemustaka aktual maupun potensial melalui program bimbingan literasi informasi ataupun pendidikan pemustaka mengenai cara melakukan sitiran dan pembuatan bibliografi dengan efisien.

Saat ini, sudah banyak aplikasi teknologi informasi yang memudahkan para penulis untuk mengoptimalkan pekerjaan mereka dalam kegiatan tulis menulis. Aplikasi utama yang diperlukan penulis sebagai pengolah kata seperti microsoft word dan mac word pada aplikasi microsoft office, open office, libre office, office 365, dan lain sebagainya. Namun aplikasi itu saja tidak cukup, perlu adanya tambahan aplikasi untuk memudahkan manajemen referensi, salah satunya menggunakan zotero. Ada beberapa keunggulan zotero dibandingkan aplikasi manajemen referensi lain (Nugroho, 2015) diantaranya: 1) Zotero dapat menyimpan file yang ada pada sebuah artikel dan dapat langsung menyimpan sitasi dari website yang sedang dibuka dan menyimpan data pustaka yang dikumpulkan sebagai basis data serta memformat sesuai dengan style yang diinginkan; 2) Zotero mampu melakukan pencarian sumber rujukan yang sudah pernah disimpan dan dibuka kembali sumber rujukan tanpa koneksi internet; dan 3) Zotero dapat berfungsi sebagai sharing sumber rujukan dengan penulis lain. Dengan memanfaatkan aplikasi manajemen referensi seperti zotero, memudahkan para calon penulis untuk melakukan pengawasan diri sebagai bentuk strategi untuk menghindari tindakan plagiarisme dan mengurangi pelanggaran yang dapat merugikan diri sendiri dan orang lain saat membuat karya ilmiah. Sehingga karya ilmiah yang dihasilkan akan sesuai dengan etika penulisan.

\section{METODE}

Pelaksanaan pengabdian kepada masyarakat ini menggunakan metode pelatihan dalam bentuk tutorial dan project-based oleh pelaksana dan asisten pelaksana, partisipatif mahasiswa, maupun metode tanya jawab seputar materi yang disampaikan saat kegiatan pelatihan manajemen referensi karya ilmiah menggunakan zotero yang berlangsung selama tiga hari, mulai dari tanggal 28 s.d 30 September 2020. Durasi kegiatan perharinya mencapai 3-4 jam persesi yang terdiri dari hari pertama diisi dengan penyampaian materi, hari kedua dan ketiga diisi dengan pelatihan yang dipandu secara daring. Pelatihan dilakukan dengan situasi yang wajar (natural setting), berdasarkan fenomena dan tingkah laku mahasiswa pada situasi tersebut. Peserta dalam pelatihan ini sekaligus bertindak sebagai informan adalah mahasiswa program studi D3 Perpustakaan FKIP Universitas Tanjungpura yang sedang menyusun tugas akhir sebagai syarat kelulusannya, mahasiswa tingkat 2 , dan mahasiswa tingkat 1 dengan total peserta sebanyak 60 orang.

Untuk mengukur tingkat keberhasilan dan mendapatkan umpan balik dari kegiatan ini, maka perlu dilakukan tahapan analisis data. Aktivitas dalam analisis data dan evaluasi dilakukan secara interaktif dan berlangsung secara terus menerus 
Lain halnya jika suatu karya ilmiah tidak dilakukan dengan jujur ataukeluar darijalurnya, maka bisa memberikan dampak negatif bagi pembacanya atau lebih dikenal dengan informasi hoax. Hal ini yang perlu dihindari. Oleh sebab itu, originalitas harus selalu dijunjung tinggi. Permasalahannya sekarang, kaitan antara kewajiban membuat sebuah karya ilmiah dengan keharusan penulisan tersebut secara jujur. Banyak oknum-oknum akademisi terutama mahasiswa yang mengabaikannya sehingga merugikan penulis aslinya karena mengambil sebuah karya yang ada di internet tanpa mencantumkan pemilik karya asli dalam tulisan ilmiahnya. Aksi tersebut tergolong kedalam tindakan plagiarisme.

\section{Plagiarisme}

Plagiarisme merupakan fenomena yang tidak asing lagi didunia akademik, bahkan meski pelakunya mengetahui bahwa tindakan tersebut merupakan kesalahan namun tetap saja banyak pelaku yang berasal dari dunia akademik yang aktif melakukan hal tersebut. Banyak pula yang mendefinisikan arti kata dari plagiarisme, akan tetapi intinya adalah pencurian karya orang lain yang diakui seolah-olah miliknya. Jika ditarik mundur ke belakang, ada beberapa penelitian terdahulu yang membahas mengenai aksi plagiarisem. Zimerman meneliti plagiarisme pada mahasiswa internasional di Amerika, dan menyimpulkan pentingnya peran perpustakaanperpustakaan sebagai sumber mengutip yang benar bagi mahasiswa internasional (Zimerman, 2012). Ia manyatakan sulitnya mengatasi plagiarisme karena kendala bahasa Inggris, budaya menyalin semasa pendidikan tingkat awal, dan tidak semua mahasiswa terlatih bagaimana merujuk referensi dengan benar.

Selain Zimerman, Bakhtiyari dkk meneliti metode etis dan tidak etis dalam pencegahan plagiarisme dalam tulisan ilmiah (Bakhtiyari, Salehi, Embi, \& Shakiba, 2014). Adanya jeda waktu antara membaca sumber bacaan dan menulis diyakini akan mengurangi risiko plagiarisme. Adanya jeda waktu antara membaca sumber bacaan dan menulis diyakini akan mengurangi risiko plagiarisme. Lain lagi hasil penelitian yang dilakukan oleh Heckler meneliti 2.826 partisipan yang mengambil mata kuliah pengantar sosiologi di Universitas Alabama berupa arsip tugas mahasiswa beberapa tahun terakhir dengan hasil :

Hasil tulisan dianalisis menggunakan aplikasi turnitin untuk memeriksa persentase overlap. Kategori overlap $0,1-24 \%, 50-74 \%, 75-99 \%$, dan $100 \%$. Pada penelitian Lewis dan Zhong (2011) diperoleh beberapa alasan yang mendasari responden melakukan plagiarisme seperti kemalasan 29,6\%, terdesak waktu $(19,5 \%)$, internet mempermudah $(19,3 \%)$,kesalahan tidak disengaja (18\%), meragukan kemampuan sendiri untuk menyelesaikan tugas tanpa mengopi $(2,5 \%)$, aturan-aturan yang tidak jelas(1,9\%), mendapat diploma lebih penting dari pada pertimbangan lainnya $(1,7 \%)$ penugasan tidak berharga untuk mengerjakan kerja orisinil $(0,6 \%)$, universitas tidak mengambil langkah serius $(0,2 \%)$, profesor/dosen memalingkan muka ( $0 \%)$.

Tabel 1. Tugas Mahasiswa Mata Kuliah Sosiologi Universitas Albama

\begin{tabular}{cc}
\hline Tahun angkatan & Jumlah tulisan \\
\hline 2008 & 1429 \\
2009 & 1588 \\
2010 & 1614 \\
\hline \multicolumn{2}{r}{ Sumber: (Heckler, Forde, \& \& Bryan, 2013) }
\end{tabular}

\section{Pelatihan Manajemen Referensi menggunakan Zotero}

Antusias para peserta sudah terlihat saat sesi pendaftaran dibuka, sebanyak 60 orang pendaftar yang terdiri dari mahasiswa aktif maupun alumni. Direncanakan target awal kegiatan hanya para mahasiswa tingkat akhir dengan tujuan membantu mereka untuk mempercepat penyusunan tugas akhir namun ternyata respon dari mahasiswa tingkatan di bawahnya juga positif. Sehingga mereka turut serta mendaftarkan diri mengikuti kegiatan ini. Bahkan alumni juga ikut berpartisipasi. Jika dirincikan sebanyak $48,3 \%$ peserta berasal dari semester 5 (tingkat akhir/ketiga), 41,7\% peserta berasal dari semester 1 (tingkat pertama), dan 10\% peserta berasal dari semester 3 (tingkat kedua).

Selama tiga hari berturut-turut, tim pelaksana pengabdian mendapati bahwa sebagian besar peserta mengikuti kegiatan ini dikarenakan belum mengetahui perangkat lunak zotero serta pemanfaatannya.

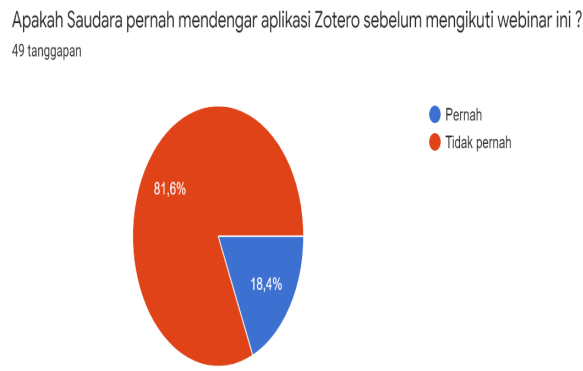

\section{Gambar 1. Pengetahuan terhadap Zotero}

Berdasarkan kajian respon 49 peserta yang konsisten mengikuti kegiatan dari hari pertama hingga hari ketiga, sebanyak $81,6 \%$ belum pernah mendengar perangkat lunak ini sebelumnya dan hanya $18,4 \%$ yang sudah mengetahui perangkat lunak zotero sehingga tujuan mereka mengikuti pelatihan untuk memperdalam keterampilannya. Hal ini yang menjadi pemicu untuk mereka mengetahui lebih jelas pemanfaatan zotero dan membantu kelancaran proses pembelajaran dan penulisan karya 
sampai tuntas (Miles and Huberman, 1994), sehingga datanya jenuh dengan tahapan sebagai berikut: 1) pengumpulan data, dilakukan dengan observasi partisipasi yang mana tim pelaksana pengabdian terjun langsung ke lapangan untuk melakukan pelatihan dan pembimbingan kepada para mahasiswa, wawancara mendalam, dan dokumentasi; 2) reduksi data, dilakukan dengan cara mereduksi data yang terkumpul hasil dari wawancara terstruktur dan observasi. Tim pelaksana pengabdian hanya memilih data yang relevan dengan tema yang diteliti agar sesuai dengan fokus permasalahan sehingga penjelasan dari jawaban informan yang tidak berkaitan maupun keluar dari topik penelitian, disingkirkan; 3) penyajian data, dilakukan dengan menggambarkan data secara naratif dan didukung dengan tabel; dan terakhir 4) penarikan kesimpulan dan verifikasi data, dilakukan dengan menarik hasil analisis deskriptif mengenai urgensi pemahaman manajemen referensi sebagai strategi meminimalisir tindakan plagiarisme yang dilakukan para mahasiswa pada saat membuat karya ilmiah.

Untuk menguji nilai kebenarannya (kredibilitas), tim pelaksana pengabdian melakukan member check untuk proses pengecekkan data evaluasi yang dilakukan oleh tim pelaksana pengabdian pada saat selesai pelaksanaan pelatihan ini. Sebanyak 11 peserta kegiatan menjadi perwakilan member check guna mengukur kesesuaian antara konsep manajemen referensi dengan plagiarisme yang tim pelaksana pengabdian pahami dengan yang peserta pahami serta triangulasi waktu untuk menjaga informasi selalu terkini sesuai dengan kondisi peserta. Untuk menguji konsistensi dan netralitas dilakukan dengan audit trail.

\section{HASIL DAN PEMBAHASAN}

Berdasarkan hasil kajian yang dilakukan oleh tim pengabdian melalui pendekatan observasi dan wawancara terhadap peserta sekaligus informan dalam kegiatan ini, beberapa permasalahan yang mendorong mahasiswa melakukan tindakan pelanggaran (plagiarisme) terjadi karena adanya faktor seperti: 1). ketidaktahuan, 2). ketidaksengajaan, 3). ketidakmampuan dalam menggunakan informasi yang diperoleh dari beberapa sumber informasi kemudian mensintesis dan menyajikan informasi tersebut, 4). kurangnya wawasan dan keterbatasan pengetahuan terkait topik yang dibahas, dan terakhir 5). Keterbatasan waktu penyelesaian pekerjaan. Dampaknya bisa terlihat dari karya yang dihasilkan. Sekilas mungkin terlihat bagus dari struktur katanya, cara menjelaskan poin demi poin objek yang dibahas akan tetapi semakin sering seseorang membaca publikasi ilmiah maka semakin mudah bagi seseorang untuk mengindentifikasi keaslian sebuah karya tulis.

Hal tersebut perlu diwaspadai sehingga perlu sedini mungkin memberikan edukasi dan melatih agar menjadi suatu kebiasaan baik bagi peserta didik seperti halnya mahasiswa. Ini akan menjadi keterampilan yang dapat membantu mereka bekerja nantinya sebagai pustakawan. Pustakawan tidak hanya berkewajiban mengelola koleksi perpustakaan saja, tetapi juga bertugas sebagai pembimbing dan pendidik masyarakat yang dilayaninya. Melalui kegiatan pelatihan diharapkan mampu melatih mahasiswa untuk terampil menggunakan aplikasi manajemen referensi zotero yang populer di kalangan akademisi dan peneliti.

Dalam kegiatan ini, tim memperjelas lagi bahwa masyarakat sasaran kegiatan ini yakni para mahasiswa tingkat akhir program studi D-3 Perpustakaan namun tidak menutup kemungkinan mahasiswa dari program studi lain juga dapat berpartisipasi. Hal tersebut dikarenakan kasus dalam tiga tahun terakhir ini, banyak mahasiswa tingkat akhir yang lalai memasukkan sumber referensi yang mereka gunakan sebagai acuan dalam pengutipan tugas akhir. Sehingga menyebabkan ada banyak temuan pada saat proses bimbingan tugas akhir bahkan pada saat proses ujian tugas akhir berlangsung seperti mereka mengutip langsung maupun tidak langsung untuk memperkuat pemaparan mereka di tugas akhir namun tidak mencantumkan sumber yang digunakan di daftar pustaka. Lebih parahnya lagi, mereka melakukan plagiarisme parsial dan antarbahasa terhadap sumber yang mereka gunakan dan tidak mencantumkan sumber tersebut di daftar pustaka. Kejadian ini mendorong kegiatan pelatihan ini menjadi penting sebagai solusi dari permasalahanpermasalahan tersebut.

\section{Karya Ilmiah}

Karya ilmiah diartikan sebagai "jenis karya tulis yang disusun berdasarkan hasil penelitian yang memenuhi syarat-syarat ilmiah tertentu dan digunakan untuk tujuan tertentu" (Agam, 2015). Agam juga menambahkan jika karya ilmiah bisa saja menjadi wacana karena di dalamnya terdapat tiga hal: ide kreatif yang didukung dasar filosofi yang kuat, gagasannya memiliki pengaruh melampaui disiplinnya, dan pemikirannya dapat dibuktikan kebenarannya. Karya ilmiah menjadi syarat mutlak bagi seorang mahasiswa untuk menyelesaikan jenjang perkuliahannya maupun dalam keseharian proses perkuliahan. Pada hakikatnya, penulisan karya ilmiah bagi para akademisi memiliki manfaat besar bagi pengembangan keilmuan dan pengetahuan sesuai bidang kajiannya, selama dilakukan dengan kaedah-kaedah yang benar maka pembaca karya tersebut akan memperoleh manfaat. 
ilmiah. Tentu saja alasan tersebut bisa dimaklumi, di satu sisi perangkat lunak ini tidak cukup terkenal jika dibandingkan dengan perangkat lunak lainnya seperti mendeley yang jauh lebih populer dikalangan akademisi. Namun bukan berarti zotero tidak dalam kategori perangkat lunak yang baik untuk manajemen referensi.

Ada beberapa keunggulan zotero (Nugroho, 2015) diantaranya: 1) Zotero dapat menyimpan file yang ada pada sebuah artikel dan dapat langsung menyimpan sitasi dari website yang sedang dibuka dan menyimpan data pustaka yang dikumpulkan sebagai basis data serta memformat sesuai dengan style yang diinginkan; 2) Zotero mampu melakukan pencarian sumber rujukan yang sudah pernah disimpan dan dibuka kembali sumber rujukan tanpa koneksi internet; dan 3) Zotero dapat berfungsi sebagai sharing sumber rujukan dengan penulis lain. Meskipun dalam pelaksanaannya para peserta cukup mengalami kesulitan di beberapa tahapan bimbingan teknis, namun tetap membuat mereka semangat mempelajari pengaplikasian zotero. Materi yang sangat dibutuhkan oleh para peserta berdasarkan kajian digolongkan menjadi 3 topik:

Apakah materi yang sangat Saudara butuhkan untuk menunjang perkuliahan? 49 tanggapan

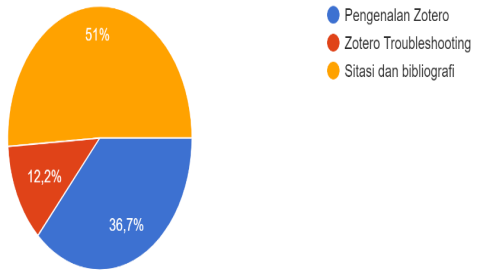

Gambar 2. Topik materi yang dibutuhkan peserta

Materi yang dibahas pada pelatihan memberikan pengalaman tersendiri bagi masing-masing peserta sehingga dari tiga topik besar tersebut, sebanyak $63,3 \%$ merasa bahwa pengetahuan kognitif maupun kemampuan afektifnya bertambah. Sebagian besar lainnya menganggap bahwa materi yang diberikan terlalu sulit dipahami sehingga mereka gagal pada saat pelaksanaan bimbingan teknis berlangsung seperti data diagram kajian tim pelaksana berikut ini:

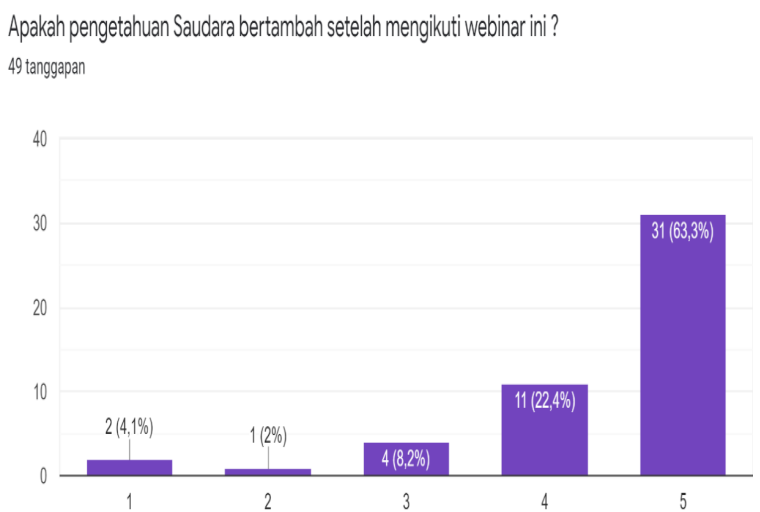

Gambar 3. Pengetahuan dan Kemampuan Peserta
Tim pelaksana menyadari bahwa masih banyak kekurangan dalam pelaksanaan webinar berbasis pelatihan ini. Untuk pertama kalinya kegiatan bimbingan teknis secara daring dilakukan. Dari segi antusias, kami menyadari bahwa kami berhasil mengundang partisipasi dan rasa keingitahuan mereka terhadap materi manajemen referensi karya ilmiah namun di sisi lain kami juga merasa bahwa memang beberapa kendala yang kami hadapi seperti jaringan internet, kurangnya referensi studi kasus untuk mempermudah pemahaman peserta, serta alokasi waktu yang sangat terbatas untuk melaksanakan pelatihan ini.

Sebagai upaya perbaikan, tim pelaksana berusaha merangkum masukan demi masukan yang kami sediakan di sesi terakhir acara agar menjadi evaluasi dan rencana perbaikan kegiatan pengabdian kepada masyarakat program studi kami ke depannya. Dari hasil kajian tersebut diperoleh bahwa 61\% peserta menginginkan adanya webinar lanjutan dengan materi zotero, $33,7 \%$ peserta menginginkan adanya webinar mengenai mendeley, dan 5,3\% peserta tidak memberikan saran. Data tersebut akan menjadi dasar perbaikan tim pelaksana di kegiatan selanjutnya.

Setelah melakukan pemantauan pada satu semester berjalan setelah pelaksanaan pelatihan ini, ternyata masih banyak mahasiswa yang melakukan plagiarisme partial. Beberapa pelanggaran itu terjadi ketika mereka sedang dalam proses pembuatan makalah, tugas praktek, dan bahkan laporan tugas akhir. Menindaklanjuti kasus yang terjadi, maka mahasiswa diberikan pembinaan dan bimbingan kembali untuk mengatasi permasalahan plagiarisme tersebut.

Adapun strategi yang dapat digunakan untuk menghindari aksi plagiarisme di kalangan mahasiswa menggunakan aplikasi zotero meliputi: 1). Lakukan sinkronisasi aplikasi zotero pada google docx, microsoft word, maupun browser yang sering digunakan. Aplikasi zotero yang sudah diunduh, hendaknya ditautkan dengan aplikasi pendukung penulisan dan browser. Hal ini akan memudahkan penulis saat melakukan penulisan secara langsung. Misalnya pada saat menulis, penulis mencari informasi di internet, maka penulis tersebut bisa langsung melakukan penyitiran dalam tulisannya. Kesigapan ini akan menekan kelalaian penulis memasukkan sumber kutipan pemikiran pakar lain; 2). Simpan sumber informasi yang relevan dan utuh di internet pada akun zotero. Sinkronisasi tersebut akan memudahkan penulis untuk menyimpan secara otomatis pada database zotero baik secara online maupun standalone terhadap sumber referensi bacaan yang digunakan saat melakukan penulisan sehingga ketika sewaktu-waktu penulis 
membutuhkannya, penulis dapat langsung menelusur pada zotero online ataupun standalone; 3). Baca sumber dengan baik, kemudian lakukan parafrase. Penulis harus menyadari kebetuhan informasinya dalam penulisan, apakah untuk memperkuat pernyataan penulis dan/atau membandingkan atau mempertentangkan pernyataan penulis. Jika sudah memastikan kebutuhannya tersebut, maka penulis bisa melakukan kutipan langsung atau tidak langsung namun sebaiknya lakukan parafrase untuk tetap menjamin orisinalitas penulisan; 4). Lakukan sitasi berupa body note ataupun foot note dengan mengklik add citation pada menu zotero di toolbar microsoft word. Banyak cara melakukan sitasi pernyataan pakar, namun ada baiknya penulis menyisipkan sitasi tersebut dengan baik sesuai aturan penulisan karya ilmiah, baik berupa body note ataupun foot note. Dalam upaya menekan kelalaian penulis, langkah ini dapat dilakukan; serta 5). Siapkan daftar pustaka di akhir halaman penulisan dengan mengklik add bibliography pada menu zotero di toolbar microsoft word. Penulis sebaiknya membiasakan diri untuk langsung mengklik menu tersebut agar sumber yang digunakan dalam pengutipan penulisan terekam dalam karya tulis. Ini berguna agar tidak ada satupun sumber kutipan yang terlewatkan tercantum pada bibliografi karya tulis penulis.

Pada saat melakukan penulisan, mahasiswa bisa meninjau ulang kembali tulisannya, melakukan interpretasi jika diperlukan untuk lebih menekankan originalitas tulisannya. Bahkan jika diperlukan, lakukan pengecekkan plagiarisme menggunakan beberapa aplikasi anti plagiarisme seperti Turnitin, iThenticate, Plagscan, dan lain sebagainya. Bagaimanapun, lingkungan akademik yang tidak membiasakan para sivitas akademikanya untuk menjunjung tinggi keteladanan, kejujuran, dan keikhlasan saat menerapkan kegiatan tri dharma maka akan menumbuhsuburkan perilaku kurang terpuji dan membudaya seperti aksi plagiarisme baik yang disadari maupun yang tidak disadari pada karya tulisannya.

\section{SIMPULAN}

Manajemen referensi karya ilmiah menggunakan zotero merupakan pengalaman baru bagi sebagian peserta webinar. Zotero merupakan salah satu solusi aplikasi yang tepat untuk memperlancar penulisan ilmiah yang bukan hanya dibuat saat tugas akhir saja tetapi juga dalam keseharian proses perkuliahan. Keterbatasan pengetahuan terhadap manajemen referensi menjadi salah satu pemicu terjadinya pelanggaran etika penulisan yang menyebabkan plagiarisme terjadi baik secara disengaja maupun tidak disengaja. Pelaku terbesar seperti mahasiswa perlu dibimbing sejak dini agar menguasai manajemen referensi sehingga dapat mempermudah proses pembelajaran secara daring maupun penulisan ilmiah tugas akhir mahasiswa tingkat ketiga. Adapun strategi yang dapat digunakan untuk menghindari aksi plagiarisme di kalangan mahasiswa menggunakan aplikasi zotero meliputi: 1). Lakukan sinkronisasi aplikasi zotero pada google docx, microsoft word, maupun browser yang sering digunakan, 2). Simpan sumber informasi yang relevan dan utuh di internet pada akun zotero, 3). Baca sumber dengan baik, kemudian lakukan parafrase, 4). Lakukan sitasi berupa body note ataupun foot note dengan mengklik add citation pada menu zotero di toolbar microsoft word, 5). Siapkan daftar pustaka di akhir halaman penulisan dengan mengklik add bibliography pada menu zotero di toolbar microsoft word.

\section{DAFTAR PUSTAKA}

Agam, R. (2015). Menulis Karya Ilmiah. Yogyakarta: Familia.

Ahoward. (2016, January 16). Quick Start Guide. Retrieved from Zotero: https://www.zotero. org/download/promote/quick_start_guide.pdf

Arifin, B. M. (2016). Teknik Penulisan Karya Ilmiah. Yogyakarta: Ar-ruz Media.

Bakhtiyari, K., Salehi, H., Embi, M., \& Shakiba. (2014). Ethical and unethical methods of plagiarism prevention in academic writing. International Education Studies 7 (7), 52 - 62.

Budiharso, T. . (2016). Panduan Lengkap Menulis Karya Ilmiah. Pontianak: Derwati Press.

Gelar Profesor banyu Juga akan Dicopot. (2010, Februari 9). Diakses pada November 5, 2021 dari artikel https://news.detik.com/ berita/d-1296139/gelar-profesor-banyu-jugaakan-dicopot

Glassman, N. R. (2018). Citation management tools : a practical guide for librarians. Lanham: Rowman \& Littlefield.

Heckler, N., Forde, D., \& \& Bryan, C. (2013). Using Writing Assignment designs to mitigate plagiarism. Teaching Sociology 41 (1), 94 105.

Indriati, E. (2015). Strategi Hindari Plagiarisme. Jakarta: Gramedia Pustaka Utama.

Kasus Plagiarisme, Anggito Abimanyu mundur dari UGM. (2014, Februari 17). Diakses pada November 5, 2021 dari artikel https://www. merdeka.com/peristiwa/kasus-plagiarismeanggito-abimanyu-mundur-dari-ugm.html 
Kementerian Pendidikan dan Kebudayaan. (2010). Peraturan Menteri Pendidikan dan Kebudayaan No.17 tahun 2010 tentang Pencegahan dan Penanggulangan Plagiat di Perguruan Tinggi. Diakses pada November 5, 2021 dari https://jdih.kemdikbud.go.id/detail peraturan?main $=594$

Lewis, N., \& Zhong, B. (2011). The Personality of Plagiarism. Journalism \& Mass Communication Educator 66 (4), 325 - 339.

Miles, M.B., and Huberman, A.M. (1994).Qualitative Data Analysis, $2^{\text {nd }}$ Ed. Newbury Park, CA: Sage.

Nugroho, R. A. (2015). Mudah Membuat Referensi \& Bibliografi. Yogyakarta: Deepublish.

Ober, H., Simon, S., \& Elson, D. (2013). Five Simple Rules to Avoid Plagiarism. Annals of Biomedical Engineering 41 (1), 1-2.

Purwoko. (2015). Manajemen Dokumen Ilmiah: menggunakan zotero dan mendeley. Yogyakarta: Aswaja Pressindo.
Salbiah, N.A. (Ed.). (2021, April 27). Kasus Plagiarisme di Tingkat SD hingga SMA Capai 94 Persen. Diakses November 5, 2021 dari https://www.jawapos.com/nasional/ pendidikan/27/04/2021/kasus-plagiarisme-ditingkat-sd-hingga-sma-capai-94-persen/

Sudiro. (1995, Juli). Bibliografi: langkah-langkah penelusuran dan penyusunan. Diakses pada Desember 6, 2020 dari artikel Perpustakaan Nasional Republik Indonesia: https:// www.perpusnas.go.id/magazine-detail. php?lang=id\&id=8179

Undang-undang No.20 tahun 2003 tentang Sistem Pendidikan Nasional. Diakses November 5, 2021 dari https://peraturan.bpk.go.id/Home/ Details/43920/uu-no-20-tahun-2003

Utama, A. (Ed.). (2017, September 28). Rektor UNJ dicopot Sementara, gelar S3 doktor plagiat "sepatutnya juga dibatalkan. Diakses pada November 5, 2021 dari artikel https://www. bbc.com/indonesia/indonesia-41416802

Zimerman, M. (2012). Plagiarism and International Students in Academic Libraries. New Library World 113 (5), 290 - 299. 